\title{
Cyclophosphamide in frequent-relapsing or steroid-dependent nephrotic syndrome: Review of 38 patients
}

\author{
Yulia Iriani, MD; Taralan Tambunan, MD; Sudigdo Sastroasmoro, MD, PhD
}

\begin{abstract}
Background Steroid-sensitive nephrotic syndrome (SSNS) in children is characterized by relapsing courses in a substantial proportion of affected individuals. Children with frequent-relapsing nephrotic syndrome (FRNS) or steroid-dependent nephrotic syndrome (SDNS) are at risk of severe steroid toxicity and need individualized treatment. Previous studies have elucidated that cyclophosphamide (CPA) reduced the risk of relapses and increased the length of subsequent remissions in children with relapsing SSNS. Methods This retrospective study evaluated 38 patients (26 FRNS and 12 SDNS) after cyclophosphamide therapy to elucidate the efficacy of CPA in FRNS or SDNS in the Department of Child Health, Cipto Mangunkusumo Hospital. All patients were treated with CPA ( $2 \mathrm{mg} / \mathrm{kg}$ per day) for 8 weeks, in combination with prednisone.

Results The median (range) duration of follow up was 45 months (24-140 months) for FRNS and 29 months (24-63 months) for SDNS. The mean relapse rate one year prior to CPA therapy in FRNS and SDNS were 3.8 relapses/year $(95 \% \mathrm{Cl} 3.4 ; 4.2)$ and 4.0 relapses/year $(95 \% \mathrm{Cl} 3.3 ; 4.7)$, which were reduced to 1.6 relapses/ year $(95 \% \mathrm{Cl} 1.1 ; 2.1)$ and 2.3 relapses/year $(95 \% \mathrm{Cl} 1.5 ; 3.2)$, respectively. The overall rate of cumulative sustained good response (complete remission or infrequent relapses) was $65 \%$ after 36 months. Frequent relapsing versus steroid-dependent status was significantly correlated with rate of sustained good response after 36 months ( $85 \%$ versus $15 \%)$ with OR=23 $(95 \% \mathrm{Cl} 3.1 ; 225.2)$.

Conclusion The efficacy of cyclophosphamide therapy in the management of FRNS is better than in SDNS [Paediatr Indones 2005;45:18-23].
\end{abstract}

Keywords: nephrotic syndrome, frequent relapse, steroid dependent, cyclophosphamide



ephrotic syndrome (NS) is the most frequent glomerular disease encountered during childhood ${ }^{1}$ with minimal change disease being the underlying histopathology in more than $85 \%$ of cases. ${ }^{2}$ Overall, approximately $80-90 \%$ children respond to initial corticosteroid therapy, but $76-93 \%$ relapse. Approximately half of the relapse children experienced frequent relapses or became steroid dependent that impaired their quality of life. ${ }^{3,4}$ Patients with frequent relapsing nephrotic syndrome (FRNS) or steroiddependent nephrotic syndrome (SDNS) are at risk of severe steroid toxicity, mainly because of the frequency with which they are exposed to continuous, high-dose prednisone to induce remission. ${ }^{5} \mathrm{~A}$ substantial number of frequent-relapsing or steroid-dependent nephrotic children require additional administration of an immunosuppressant, such as cyclophosphamide. , $7^{2}$

Cyclophosphamide (CPA) has been used in the treatment of childhood nephrotic syndrome since 1963. It was initially shown to be effective in prolonging remission but the potential carcinogenic and infertility side effects have limited its use to only one or two courses of 8 to 12 weeks. ${ }^{5}$ The usage of CPA has been evaluated in cases of steroid-resistant NS at the Department of Child Health, Cipto Mangunkusumo Hospital in the year $1975,{ }^{8}$ it was

From the Department of Child Health, Medical School, University of Indonesia, Jakarta, Indonesia.

Reprint requests to: Taralan Tambunan, MD, Department of Child Health, Medical School, University of Indonesia, Cipto Mangunkusumo Hospital, Jakarta, Indonesia. Tel. 62-21-3907740, Fax. 62-21-3907743. 
Yulia Iriani et al: Cyclophosphamide in frequent-relapsing or steroid-dependent nephrotic syndrome

routinely used as a second line immunosuppresive agent following a steroid regimen. ${ }^{8,9}$ To evaluate the efficacy of cyclophosphamide for inducing longterm remission in FRNS or SDNS, we analyzed children treated with this regimen.

\section{Methods}

We reviewed children aged 1 to 18 years suffering from primary steroid-responsive NS who relapsed frequently or developed steroid dependence and had been treated with CPA as the second-line immunosuppresive therapy. All children received initial prednisone therapy for NS in the Department of Child Health, Cipto Mangunkusumo Hospital between January 1985 and August 2000.

The definition and criteria for nephrotic syndrome, remission, and relapse were the same as those used by the International Study of Kidney Disease in Children (ISKDC). ${ }^{10}$ Nephrotic syndrome was characterized by heavy proteinuria $\left(>40 \mathrm{mg} / \mathrm{m}^{2} / \mathrm{h}\right)$ and hypoalbuminemia $(<2.5 \mathrm{~g} / \mathrm{dl})$, also often associated with edema and hypercholesterolemia (>250 mg/dl). Steroid-dependent patients were defined as those in whom two consecutive relapses occurred during the alternate-day prednisone treatment regimen given for an earlier relapse; or within 14 days after the end of an alternate-day prednisone regimen. Relapse was defined by the appearance of proteinuria $>4 \mathrm{mg} / \mathrm{m}^{2} / \mathrm{h}(2+$ protein or more by Albustix $)$ on three consecutive days, after a known period of remission. A patient was classified as a frequent relapser if he/she experienced more than 1 relapse during any 6 month period or more than 3 relapses during any 12 month period. Steroid resistance was defined as no remission after a minimum of 8 consecutive weeks of prednisone therapy. Complete remission was defined as a reduction in urinary excretion of protein to $\leq 4 \mathrm{mg} / \mathrm{m}^{2} / \mathrm{h}$ for 3 consecutive days. ${ }^{10,11}$

In children who were diagnosed as FRNS or SDNS, all relapses were treated with prednisone $60 \mathrm{mg} / \mathrm{m}^{2}$ per day initially for two weeks. After remission had been induced, CPA ( $2 \mathrm{mg} / \mathrm{kg}$ per day) were given for $8-12$ weeks in combination with prednisone (2/3 of initial dose). Prednisone therapy was discontinued at the same time of stopping CPA. This was the standard cyclophosphamide therapy for FRNS and SDNS in our unit.
Statistical analysis was performed using SPSS 11.5 for Windows and Epi Info. The relapse rate (relapses per year) during 1 year prior to and after CPA was expressed as mean and $95 \%$ confidence interval (CI). Kaplan-Meier analysis was performed to calculate the proportion of patients in complete remission and infrequent relapse (good response). The difference between the survival curves of FRNS and SDNS was analyzed with generalized Wilcoxon's test. A P value of less than 0.05 was defined to indicate a significant difference.

\section{Results}

There were 190 NS patients traced from clinical records who received initial prednisone therapy in our unit between January 1985 - August 2000. The number of NS patients during that time was actually larger but some patients who had received initial prednisone treatment at other hospitals or who were monitored less than 2 years were not included as the subjects of this study. Among 171 steroid responders, 64 patients became frequent relapsers or steroid dependent and only 59\% of them (26 frequent relapsers and 12 steroid dependent patients) were treated with CPA and matched the inclusion criteria.

Tables 1 and 2 show patient characteristics and baseline clinical characteristics at the beginning of CPA therapy. Patients were grouped as SDNS and FRNS. None had hematuria. Hypertension which had occurred in 5 patients was controlled with captropril and/or furosemide.

Median duration of follow up was 45 months (range $24-140$ months) for FRNS and 29 months (range 24 63 months) for SDNS, and all were followed up for at least two years. All patients had an eight-week course of CPA at a dosage of $2 \mathrm{mg} / \mathrm{kg}$ per day.

Following the CPA therapy, five patients in FRNS group remained in complete remission without any relapse for two years; in contrast, none in the SDNS group was in remission. The number of relapses in one year after initial remission to CPA therapy was significantly reduced in both groups (Table 3 ).

The association between the response to CPA therapy and to initial prednisone at the end of observation period can be seen in Table 4. Patients with FRNS showed a better response than those with SDNS. 
Table 1. Distribution of patient ChaRACteristics at the beginNing of CPA therapy

\begin{tabular}{|c|c|c|c|}
\hline Patient characteristics & $\begin{array}{l}\text { SNRS } \\
N=12\end{array}$ & $\begin{array}{l}\text { FRNS } \\
\mathrm{N}=26\end{array}$ & Statistics \\
\hline \multicolumn{4}{|l|}{ Characteristics } \\
\hline $\begin{array}{r}\text { Gender: Male } \\
\text { Female }\end{array}$ & $\begin{array}{l}6 \\
6\end{array}$ & $\begin{array}{l}16 \\
10\end{array}$ & NS \\
\hline Age at initial NS manifestation ${ }^{*}: \begin{array}{l}\leq 6 \text { years } \\
>6 \text { years }\end{array}$ & $\begin{array}{l}10 \\
2\end{array}$ & $\begin{array}{l}9 \\
17\end{array}$ & $\begin{array}{l}x^{2}=5.97 ; p=0.015 ; O R=9.4 \\
(95 \% \text { Cl } 1.4 ; 81.2)\end{array}$ \\
\hline Age at start of $\begin{aligned} \mathrm{CPA}^{* *}: & \leq 6 \text { years } \\
& >6 \text { years }\end{aligned}$ & $\begin{array}{l}10 \\
2\end{array}$ & $\begin{array}{l}7 \\
19\end{array}$ & $\begin{array}{l}x^{2}=8.41 ; p 0.004 ; \text { OR }=13.6 \\
(95 \% \text { Cl } 1.9 ; 122.1)\end{array}$ \\
\hline \multicolumn{4}{|l|}{ Clinical manifestations } \\
\hline $\begin{array}{r}\text { Hipertension: Positive } \\
\text { Negative }\end{array}$ & $\begin{array}{l}1 \\
11\end{array}$ & $\begin{array}{l}3 \\
23\end{array}$ & NS \\
\hline $\begin{array}{l}\text { Edema: Generalized } \\
\text { Non generalized }\end{array}$ & $\begin{array}{l}8 \\
4\end{array}$ & $\begin{array}{l}10 \\
16\end{array}$ & NS \\
\hline $\begin{array}{c}\text { Nutritional status: Good - over nutrition } \\
\text { Under nutrition } \\
\text { Malnutrition }\end{array}$ & $\begin{array}{l}9 \\
2 \\
1\end{array}$ & $\begin{array}{l}19 \\
5 \\
2\end{array}$ & NS \\
\hline \multicolumn{4}{|l|}{ Laboratory findings } \\
\hline $\begin{aligned} & \text { Proteinuria: }>+1 \\
&+1\end{aligned}$ & $\begin{array}{l}12 \\
0\end{array}$ & $\begin{array}{l}21 \\
5\end{array}$ & NS \\
\hline Albumin: $\begin{aligned} & <2 \mathrm{~g} / \mathrm{dL} \\
& \geq 2 \mathrm{~g} / \mathrm{dL}\end{aligned}$ & $\begin{array}{l}3 \\
9\end{array}$ & $\begin{array}{l}8 \\
18\end{array}$ & NS \\
\hline $\begin{aligned} \text { Cholesterol: } & <350 \mathrm{mg} / \mathrm{dL} \\
& \geq 350 \mathrm{mg} / \mathrm{dL}\end{aligned}$ & $\begin{array}{l}5 \\
7\end{array}$ & $\begin{array}{l}10 \\
16\end{array}$ & NS \\
\hline GFR: $\begin{aligned} & 30-49 \mathrm{ml} / \text { minute } / 1.73 \mathrm{~m}^{2} \\
& 50-79 \mathrm{ml} / \text { minute } / 1.73 \mathrm{~m}^{2} \\
& \geq 80 \mathrm{ml} / \text { minute } / 1.73 \mathrm{~m}^{2}\end{aligned}$ & $\begin{array}{l}1 \\
3 \\
8\end{array}$ & $\begin{array}{l}1 \\
1 \\
24\end{array}$ & NS \\
\hline $\begin{array}{l}\text { Renal biopsy: MCNS } \\
\text { Not representative }\end{array}$ & - & $\begin{array}{l}2 \\
2\end{array}$ & - \\
\hline
\end{tabular}

NS = not significant

Table 2. Distribution of Baseline clinical characteristics

\begin{tabular}{|c|c|c|c|c|}
\hline \multirow[t]{2}{*}{ Variable } & \multicolumn{2}{|c|}{ Steroid-dependent } & \multicolumn{2}{|c|}{ Frequent- relapsing } \\
\hline & Mean & $95 \% \mathrm{Cl}$ & Mean & $95 \% \mathrm{Cl}$ \\
\hline Age at onset of NS (years) & 3.76 & $2.28 ; 5.25$ & 7.36 & $5.86 ; 8.86$ \\
\hline Age at start of CPA (years) & 4.63 & $3.22 ; 6.04$ & 9.07 & $8.48 ; 10.56$ \\
\hline Cumulative CPA dose $\left(\mathrm{mg} / \mathrm{m}^{2} \mathrm{BSA}\right)$ & 2739 & 2323; 31556 & 3023 & $2840 ; 3206$ \\
\hline Duration of NS before CPA (months) & 12.8 & $7.9 ; 17.7$ & 16.6 & $10.2 ; 23.1$ \\
\hline Follow up after CPA (months) & 37.8 & $27.6 ; 47.9$ & 55.0 & $41.6 ; 68.4$ \\
\hline
\end{tabular}

Table 3. Relapse rate in patients with SDNS and FRNS after CPA therapy

\begin{tabular}{llllll} 
Number of relapses per year & \multicolumn{2}{c}{ Steroid-dependent } & & \multicolumn{2}{c}{ Frequent-relapsing } \\
& Mean & $\mathbf{9 5 \%} \mathbf{~ C l}$ & & Mean & $\mathbf{9 5 \%} \mathbf{~ C l}$ \\
\hline One year before CPA therapy & 4.0 & $3.3 ; 4.7$ & & 3.8 & $3.4 ; 4.2$ \\
One year after initial remission after CPA therapy & 2.3 & $1.5 ; 3.2$ & 1.6 & $1.1 ; 2.1$
\end{tabular}

Table 4. Response to CPA in FRNS and SDNS

\begin{tabular}{llll}
\hline Initial response to prednisone & \multicolumn{3}{c}{ Response to CPA until the end of follow-up } \\
\cline { 2 - 4 } & Good response & Poor response & Statistics \\
\hline Frequent-relapsing NS & 9 & 3 & $\begin{array}{l}\text { Yates corrected } x^{2}=12.51 ; \\
\text { P=0.000; OR=23.00I } \\
(95 \% \mathrm{Cl} 3.02 ; 229.25)\end{array}$ \\
Steroid-dependent NS & 3 & 23 &
\end{tabular}


The cumulative rate of sustained good response was analyzed in all patients, SDNS and FRNS patients, using the life table analysis method (Figure 1). The overall rate of cumulative sustained good response was $65 \%$ after 36 months. Patients with FRNS had a significantly higher cumulative rate of sustained good response than those with SDNS (85\% versus 15\% after 36 months, $\mathrm{P}=0.0001$ )

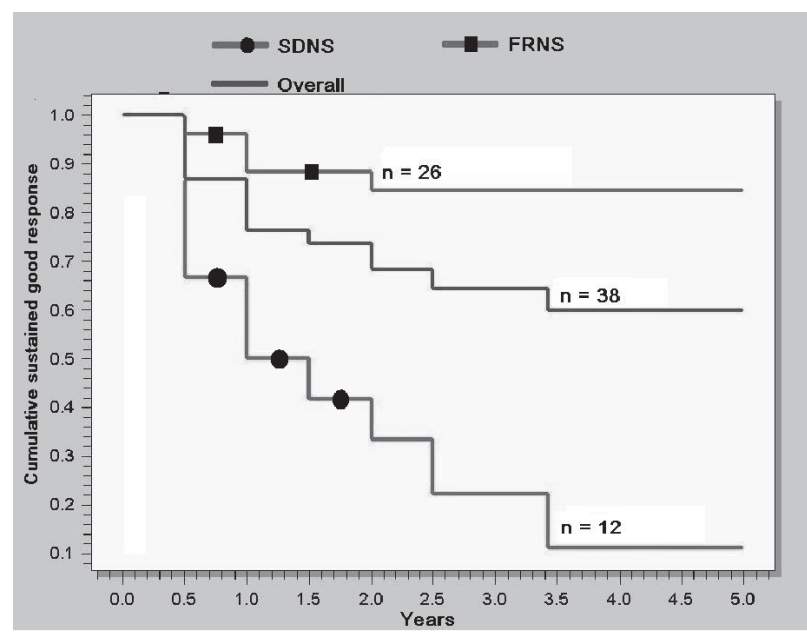

Figure 1. SUSTAINED GOOD RESPONSE OVER A PERIOD OF 5 YEARS

During CPA therapy, reversible leukopenia occurred in 5 patients and anemia in one patient. Two patients suffered from hypertension. None developed thrombocytopenia or suffered from hemorrhagic cystitis or severe infection during either the treatment or the following observation. Only one patient needed specific treatment for excessive vomiting. Four patients developed renal failure (3 SDNS and 1 FRNS). The first patient developed renal failure 70 days after remission to CPA therapy, the second patient after 270 days, the rest had suffered from hypertension at the beginning of the CPA therapy. Two patients died at the end of the observation period due to the complications of chronic renal failure, one of them had uncontrolled hypertension.

\section{Discussion}

Despite of methodological limitations of a retrospective analysis, we believe our data were valid since we included all patients treated with CPA which made our study population representative. Despite the relatively small number of treated patients, the calculated power of this study is sufficient (90\%).

The proportions of FRNS and SDNS in this study were higher than reported by Pulungan ${ }^{12}$ $\left(16.5 \%\right.$ and $7.9 \%$, respectively) and Wilawirya ${ }^{13}$ (18.9\% and $1.6 \%$, respectively). This was probably caused by the longer observation period in this study, covering the new NS patients. In 1976, ISKDC reported a higher proportion of FRNS (39\%). ${ }^{2}$ Not all FRNS and SDNS patients were treated with CPA due to financial constraint, bad compliance and no parental consent.

Steroid dependent nephrotic syndrome patients were younger at the onset of NS compared to FRNS. This result is in agreement with the study of Pennisi et al. ${ }^{14}$ and Kemper et al..$^{15}$ (age of 3.1 and 3.7 years, respectively). However, in contrast with our result, there are studies revealing that SDNS patients were older at the time when CPA therapy was started. ${ }^{14-16}$ This difference may be due to diversity of treatment schedules.

It has been a common practice to perform renal biopsy prior to the administration of alkylating agent, but Mattoo found that renal biopsy prior to the administration of CPA is not essential in patients who respond to initial corticosteroid therapy. ${ }^{17}$ In this study, renal biopsy was only performed in four patients, two of them with minimal change NS and the other two could not be histopathologically typed as the sample were not representative.

Several factors were significantly correlated with the favorable outcome i.e., duration of treatment, ${ }^{16,18,19}$ a cumulative dosage per body surface area $(\mathrm{BSA}) \leq 5040 \mathrm{mg} / \mathrm{m}^{2}$, leukopenia during CPA therapy, frequent relapsing versus steroid-dependent status, age at onset of the disease, and age when CPA therapy was started. ${ }^{20}$ Arbeitsgemeinschaft für Pädiatrische Nephrologie ${ }^{16}$ (APN) concluded that response to 12-week course of CPA therapy was better than 8 -week course, but Ueda et al. ${ }^{18}$ found no difference between 8-week and 12-week course of CPA therapy. All of our study patients had 8-week course of CPA therapy. The influence of leukopenia in this study could not be analyzed because only 3 patients developed leukopenia during CPA therapy.

Among the patients who got relapses after CPA treatment, some had a marked reduction number of 
relapses during one year after remission (Table 2). However, patients with FRNS had a significantly better response than patients with SDNS (Table 3). A similar result was obtained by Arbeitsgemeinschaft für Pädiatrische Nephrologie. ${ }^{16,21}$ Kemper et al. found that $70 \%$ SDNS relapsed and $86 \%$ of them became steroid dependent again after 2 years. ${ }^{15}$ This study revealed 2 patients became steroid dependent after 2 years. Difference in this study is probably explained by diverse patient selection, different treatment duration and small sample size.

Patients with FRNS had a significantly higher good response than patients with SDNS (85\% versus 15\% after 36 months, Figure 2). This result (in FRNS group) was higher than the studies of Vester et al. ${ }^{20}$ (54\%) and of Latta et al. ${ }^{22}$ (72\%). On the contrary, the result in SDNS group was relatively lower than other studies that used 12-week course of CPA therapy i,e., the study of $\operatorname{APN}^{18}$ (67\%), Kemper ${ }^{15}$ (30\%), and Ueda $^{16}$ (24\%). Since our cumulative dosage for BSA was lower than the threshold given by Vester et al, ${ }^{20}$ we suggest to increase the cumulative dose for SDNS which can be achieved with a longer duration of CPA therapy.

None of the patients in this study developed any serious side effect. Two patients died because of complications of chronic renal failure, one case with uncontrolled hypertension.

In conclusion, our study shows that the efficacy of cyclophosphamide is better in the management of patients with frequent realpsing nephrotic syndrome compared to those with steroid-dependent nephrotic syndrome.

\section{References}

1. International Study of Kidney Disease in Children. The primary nephrotic syndrome in children: Identification of patients with minimal change nephrotic syndrome from initial response to prednisone. J Pediatr 1981;98:561-6.

2. Barnett HL. The natural and treatment history of glomerular diseases in children - what can we learn from international cooperative studies? A report of the International Study of Kidney Disease in Children. Presented at the Sixth International Congress of Nephrology, Basel; 1976; Basel, Switzerland.
3. Koskimies O, Vilska J, Rapola J, Hallman N. Long-term outcome of primary nephrotic syndrome. Arch Dis Child 1982;57:544-8.

4. Tarshish P, Tobin JN, Bernstein J, Edelmann CMJ. Prognostic significance of the early course of minimal change nephrotic syndrome: Report of the International Study of Kidney Disease in Children. J Am Soc Nephrol 1997;8:769-76.

5. Durkan AM, Hodson EM, Willis NS, Craig JC. Immunosuppressive agents in childhood nephritic syndrome: A meta-analysis of randomized controlled trial Kidney Int 2001;59:1919-27.

6. Barrat TM, Soothill JF. Controlled trial of cyclophosphamide in steroid sensitive relapsing nephrotic syndrome of childhood. Lancet 1970;ii:479-82.

7. International Study of Kidney Disease in Children. Prospective controlled trial of cyclophosphamide in children with nephrotic syndrome. Lancet 1974;ii:423-7.

8. Wila Wirya IGN, Alatas H, Tambunan T, Khow LP, Ramelan W. The effect of cyclophosphamide in children with steroid resistant nephrotic syndrome. Paediatr Indones 1976;6:291-8.

9. Alatas H. Pengobatan rasional sindrom nefrotik anak. Presented at Simposium Penyakit Ginjal di Masyarakat, Bandung; 1985; Bandung, Indonesia.

10. A report of the International Study of Kidney Disease in Children. Nephrotic Syndrome in children: Prediction of histopathology from clinical and laboratory characteristics at time of diagnosis. Kidney Int 1978;13:159-65.

11. Nash MA, Edelmann Jr CM, Bernstein J, Barnett HL. The Nephrotic Syndrome. In: Edelmann Jr CM, editor. Pediatric Kidney Disease. $2^{\text {nd }}$ ed. Boston: Little Brown and Company; 1992. p.1247-1324.

12. Pulungan AB. Gambaran klinis dan laboratorium sindrom nefrotik primer pada anak kelompok kambuh sering dan dependen steroid [Thesis]. Jakarta: Bagian Ilmu Kesehatan Anak FKUI; 1996.

13. Wila Wirya IGN. Penelitian beberapa aspek klinis dan patologi anatomis sindrom nefrotik primer pada anak di Indonesia [dissertation]. Jakarta: Universitas Indonesia; 1992.

14. Pennisi AJ, Grushkin CM, Lieberman E. Cyclophosphamide in the treatment of idiopathic nephrotic syndrome. Pediatrics 1976;57:948-51.

15. Kemper MJ, Altrogge H, Ludwig K, Timmermann K, MullerWiefel DE. Unfavorable response to cyclophosphamide in steroid-dependent nephrotic syndrome. Pediatr Nephrol 2000;14:772-5. 
16. Ueda N, Kuno K, Ito S. Eight and 12 week courses of cyclophosphamide in nephrotic syndrome. Arch Dis Child 1990;65:1147-50.

17. Mattoo TK. Kidney biopsy prior to cyclophosphamide therapy in primary nephrotic syndrome. Pediatr Nephrol 1991;5:617-9.

18. Arbeitsgemeinschaft für Pädiatrische Nephrologie. Cyclophosphamide treatment of steroid dependent nephrotic syndrome: comparison of 8 week with 12 week course. Arch Dis Child 1987;62:1102-6.

19. Ponticelli C, Edefonti A, Ghio L, Rizzoni G, Rinaldi S, Gusmano R et al. Cyclosporin versus cyclophosphamide for patients with steroid dependent and frequently relapsing idiopathic nephrotic syndrome: a multicentre randomized controlled trial. Nephrol Dial Transplant 2003;8:1326-33.
20. Vester U, Kranz B. Cyclophosphamide in steroid-sensitive nephrotic syndrome: outcome and outlook. Pediatr Nephrol 2003;8:661-4.

21. Arbeitsgemeinschaft für Pädiatrische Nephrologie. Effect of cytotoxic drugs in frequently relapsing nephrotic syndrome with and without steroid dependence. N Engl J Med 1982; 306:451-4.

22. Latta K, Schnakenburg C, Ehrich JHH. A meta-analysis of cytotoxic treatment for frequently relapsing nephrotic syndrome in children. Pediatr Nephrol 2001; 16:271-82.

23. McCrory WW, Shibuya M, Lu WH, Lewy JE. Therapeutic and toxic effects observed with different dosage programs of cyclophosphamide in treatment of steroid-responsive but frequently relapsing nephrotic syndrome. J Pediatr 1973;82:614-8. 